\title{
POTENTIAL USE OF IRON ORE TAILINGS IN SANDCRETE BLOCK MAKING
}

\author{
H. S. Abdulrahman ${ }^{1}$ \\ ${ }^{I}$ Department of Civil Engineering, Federal University of Technology Minna
}

\begin{abstract}
Sand-Crete blocks are widely used in Nigerian construction industry. Its quality has been compromised by manufacturers mainly due to the quality and cost of materials used. Iron ore tailings (IOT) are waste material obtainable from the process of smelting of iron. The study tests suitability of IOT in replacing natural sand partially in the making of Sand-Crete Blocks (SCB). Iron ore tailing was added to the mix in the following percentage: 10\%, 20\%, 30\% and 40\% of sand. It was observed the compressive strength increases with increase in curing age and also increases in percentage of iron tailings. IOT has a great potential as a replacement of fine aggregate in sandcrete block production
\end{abstract}

Keywords: iron ore tailings, sandcrete blocks, and compressive strength.

\section{INTRODUCTION}

Over $90 \%$ of physical infrastructures in Nigeria are being constructed using sandcrete blocks (SCB) (Baiden and Tuuli, 2004). This makes SCBs a very important material in building construction. It is widely used in Nigeria, Ghana, and other African countries as load bearing and non-load bearing walling unit. For a long time in Nigeria, sandcrete blocks are manufactured in many parts of the country without any reference to suit local building requirements. The quality of blocks is a function of the method employed in the production and the properties of the constituent materials. In the hardened state, SCB has a high compressive streength and this strength increase with density. The range of minimum strength specified in Nigerian Industrial Standards; NIS 87:2007 is between $2.5 \mathrm{~N} / \mathrm{mm} 2$ to $3.45 \mathrm{~N} / \mathrm{mm} 2$. The current trend all over the world is to utilize the treated and untreated industrial byproducts as a raw material in construction, which gives an eco-friendly edge to solution to waste disposal. To achieve this objective, intensive efforts are being made in effective utilization of industrial by-products particularly from mining and mineral industries. Most literatures use IOT as a partial replacement for sand or cement in concrete, hence the need to utilize IOT as potential material hollow SCB.

\section{LITERATURE REVIEW}

The word 'sandcrete' has no standard definition; it is just a compound word gotten from sand and concrete to form a compound word Sand-Crete which is a mixture of sand, cement and water. When molded into blocks they are known as sandcrete blocks (SCB). According to NIS 87:2000, they are masonry units which when used in its normal aspect exceeds the length, width or heights specified for bricks. The block can therefore be made either in solid and hollow rectangular types (for normal wall) or decorative and perforated in different designs, patterns, shapes, sizes and types (for screen wall or sun breakers). According to BS
6073 (Specification for Precast Concrete Masonry Unit Part 1), three types of blocks are recognized: solid, hollow and cellular. They are moulded or produced in various sizes. Commonly used size is dimension of $225 \mathrm{~mm} \times 450 \mathrm{~mm} \times$ 150 mmwith a wide range of 6inches and 9 inches. The current trend all over the world is to utilize the treated and untreated industrial by-products as a raw material in construction, which gives an eco-friendly edge to solution to waste disposal. To achieve this objective, intensive efforts are being made in effective utilization of industrial byproducts particularly from mining and mineral industries.Andam (2004) showed that commercially produced sandcrete blocks exhibit compressive strength far below standard recommendation for construction. He went further to indicate that the maximum compressive strength of commercially produced sandcrete blocks was within range of $0.87 \mathrm{~N} / \mathrm{mm} 2 \mathrm{as}$ against minimum recommended standards of $3.5 \mathrm{~N} / \mathrm{mm} 2$ for 9 inches blocks.

Abdullahi (2005) investigated the strength characteristics of sandcrete blocks in Bosso and Shiroro areas in Minna, Nigeria. Five commercial sandcrete blocks were randomly selected and soil samples were also collected from each manufacturer for a period of three weeks. Sieve analysis was conducted on the soil samples and Compressive strength test were conducted on the blocks. The test results revealed that the materials used for the production of sandcrete blocks were adequate but noted that the mix ratio may have been altered for commercial gains.

Raheem (2006), considered an assessment of the quality of sandcrete blocks produced by Ladoke Akintola University Technology Block Industry. His results indicated that compressive strength of the blocks generally ranges from $0.53 \mathrm{~N} / \mathrm{mm}^{2}$ to $1.68 \mathrm{~N} / \mathrm{mm}^{2}$ for 9 inches blocks, while that of 6 inches blocks increased from $0.53 \mathrm{~N} / \mathrm{mm}^{2}$ to $1.59 \mathrm{~N} /$ $\mathrm{mm}^{2}$, this is below NIS standards 
The industry, to a great extent lacks commitment to (NIS $87: 2000)$ standard requirement which is a common problem affecting the whole sandcrete block industries in Nigeria. The weakness of Regulatory Authority in Nigeria opened ways for personal gains and business opportunity exploitation. Neville, (2000) identified that the comprehensive strength of a sandcrete materials increases with cement content. This statement implies that the type of sand materials used, such as fineness, density, relative density and sharpness seems to have direct influence on easy mixing with cement. Increase in strength with age and curing temperature, also seems to contribute to stabilization of sandcrete blocks (BS 882 1992). In general terms, the strength of SCBs can be affected by quality of materials; common to most researchers who have undertaken researches in this area noted one salient property that is cement. Manufacturers of SCB tend to reduce the quantity of cement to maximize gains.

Iron ore tailings are the materials left over after the beneficiation process of separating the valuable fraction from the worthless fraction of an iron ore. Itakpe iron ore deposits in Ajaokuta, Kogi State, Nigeria, is where such mining activities are going on, and has a total estimated reserve of about 182.5 million metric tons. It designed to treat a minimum of 24000 tons of ore per day while operating for 300 days per year (Elinwa and Maichibi 2014).

The waste material from the processing is approximately 64 $\%$ which translates into 3,072 tons/day while the output of these tailings are on the increase, proper disposal of these wastes are an important component in reducing the environmental nuisance of these wastes and also, maintaining a healthy environment. Apart from using it as secondary source and landfills, it can be gainfully used as supplementary material in the cement and concrete industries. See the table 1.0 below to for chemical content of iron ore tailings.

Table 1

\begin{tabular}{|l|l|}
\hline CHEMICAL CONTENT & PERCENTAGE \\
\hline Iron content & 15 \\
\hline Silica content & 66 \\
\hline Alumion Oxide content & 3.8 \\
\hline Calcium oxide & 1.8 \\
\hline Magnesium oxide & 1.0 \\
\hline Sulphur & 0.8 \\
\hline Phosphorus & 1.0 \\
\hline
\end{tabular}

Source: Fortune magazine, 2009

Ullas et al., (2010) carried out experimental studies on masonry units made of Iron ore tailings in compressed earth block (CEB).Optimum mix proportions of soil, sand, cement and the sand fraction is replaced by IOT at $25 \%, 50 \%$ and $100 \%$. Block characteristics like wet compressive strength, water absorption, initial rate of absorption, and linear elongation and it was found that considerable amount of sand can be replaced by IOT without compromising desirable characteristics of CEB.
Sujing et al., (2013) studied the possibility of using Iron ore tailings to replace natural aggregate to prepare ultra - high performance concrete (UHPC). It was found that the $100 \%$ replacement of natural aggregate by Iron ore tailings significantly replaced the workability and compressive strength of UHPC. However when the replacement level was not more than $40 \%$, for 90 days standard cured specimens, the mechanical behavior of the tailings was comparable to that of control mix and for specimens that were steam cured for 2 days, the compressive strengths of the tailing mixes decreased by $11 \%$ while the flexural strength increased by up to $8 \%$ compared to the control mix, in essence the replacement of IOT in concrete should be restricted to partial replacement. Huang et al., (2013) also attempt to use Iron ore tailings to develop greener engineered cementious composites (ECCs). He found that, with cement content $117.2-350.2 \mathrm{~kg} / \mathrm{m} 3$ exhibit a tensile ductility of $2.3-3.3 \%$, tensile strength of $5.1-6 \mathrm{MPa}$ and compressive strength of $46-57 \mathrm{MPa}$ at 28 days.

Mangalpady (2012) mentioned in his paper that the composition of tailings is directly dependent on the composition of the ore and the process of mineral extraction used on the ore. He studied the suitability and reliability of Iron ore tailings in manufacture of Paving Blocks. He prepared five reference mixes using cement, jelly dust and baby jelly with different mix ratios and by using sand and Iron ore tailings as fine aggregates. The results of his study showed that compressive strength of tailing based mix was higher than the respective reference mix; IOT has pozzolanic property, improves the workability of the sand for all replacement levels but only improves workability up to $10 \%$ replacement of cement.

\section{METHODOLOGY}

\subsection{Materials}

The materials used for this work includes; sharp sand, iron ore tailings (IOT), ordinary Portland cement and water.

\subsection{Methods}

For the purpose of this study, laboratory tests were conducted to determine the physical properties of the sand and IOT to be used in the production of sandcrete block (SCB). These properties include; Particle size distribution, specific gravity, moisture content and bulk density. While for the mix; slump test and compressive strength tests were carried out to determine the workability and compressive strength of the SCB.

\subsection{Production of Sandcrete Blocks}

NIS 87:2000 procedures were adopted in the production of the sandcrete blocks. The mix ratio is 1:6(one part of cement to 6 parts of sand). The sand portion was mixed with some portions of IOT as a partial replacement in the following percentages; $10 \%, 20 \%$ and $30 \%$. SCB of dimension $150 \mathrm{~mm} \times 225 \mathrm{~mm} \times 450 \mathrm{~mm}$ were molded. The SCB were kept at room temperature for 24 hours and the moulds were removed. The blocks were cured for 7, 14, 21 and 28days respectively by sprinkling water on them in the mornings and evenings. 


\section{DISCUSSION OF RESULTS}

\subsection{Results}

Specific gravity of IOT is quite higher than that of sand used and this is reflected in the bulk density of both materials. Also the particle size distribution as shown in figures 1 and 2 below of both samples indicates that the coefficient of uniformity of sand $\left(\mathrm{C}_{\mathrm{U}}=2.5\right)$ is lower than that of IOT $\left(\mathrm{C}_{\mathrm{U}}=4.5\right)$, similarly the moisture content of IOT is much lower than that of sand that explains the lowering value of slump at $30 \%$ of IOT, see table 2 for slump test results. Thus, this implies that IOT is denser than sand thus incorporating it in the SCB could increase the density of the blocks and consequently increases the compressive strength of the blocks. See table 1 for the physical properties of both sand and IOT.
Table 3: Physical Properties

\begin{tabular}{|l|l|l|l|l|}
\hline $\begin{array}{l}\text { Mate } \\
\text { rial }\end{array}$ & $\begin{array}{l}\text { Speci } \\
\text { fic } \\
\text { Grav } \\
\text { ity }\end{array}$ & $\begin{array}{l}\text { Bulk density } \\
\text { Uncompacted( } \\
\text { g/cm }\end{array}$ & $\begin{array}{l}\text { Bulk } \\
\text { density } \\
\text { Compacted( } \\
\text { g/cm }\end{array}$ & $\begin{array}{l}\text { Moistu } \\
\text { re } \\
\text { content } \\
(\%)\end{array}$ \\
\hline SAN & 2.59 & 0.74 & 2.41 & 24.71 \\
\hline IOT & 3.49 & 3.18 & 3.33 & 0.06 \\
\hline
\end{tabular}

Table 4: Slump Test Values

\begin{tabular}{|l|l|}
\hline Percentage of & Slump \\
\hline $\mathbf{0}$ & 16 \\
\hline $\mathbf{1 0}$ & 15 \\
\hline $\mathbf{2 0}$ & 12 \\
\hline $\mathbf{3 0}$ & 10 \\
\hline
\end{tabular}

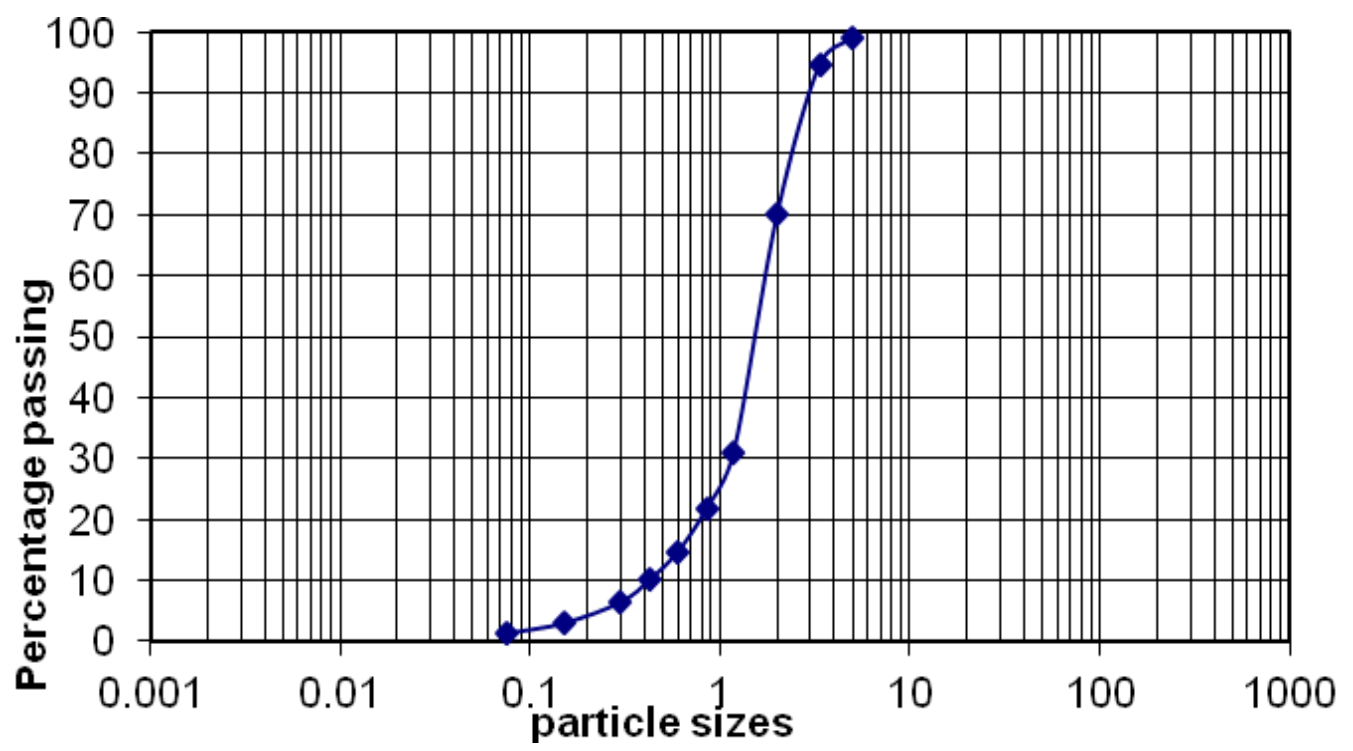

Fig 1: Particle size distribution (IOT)

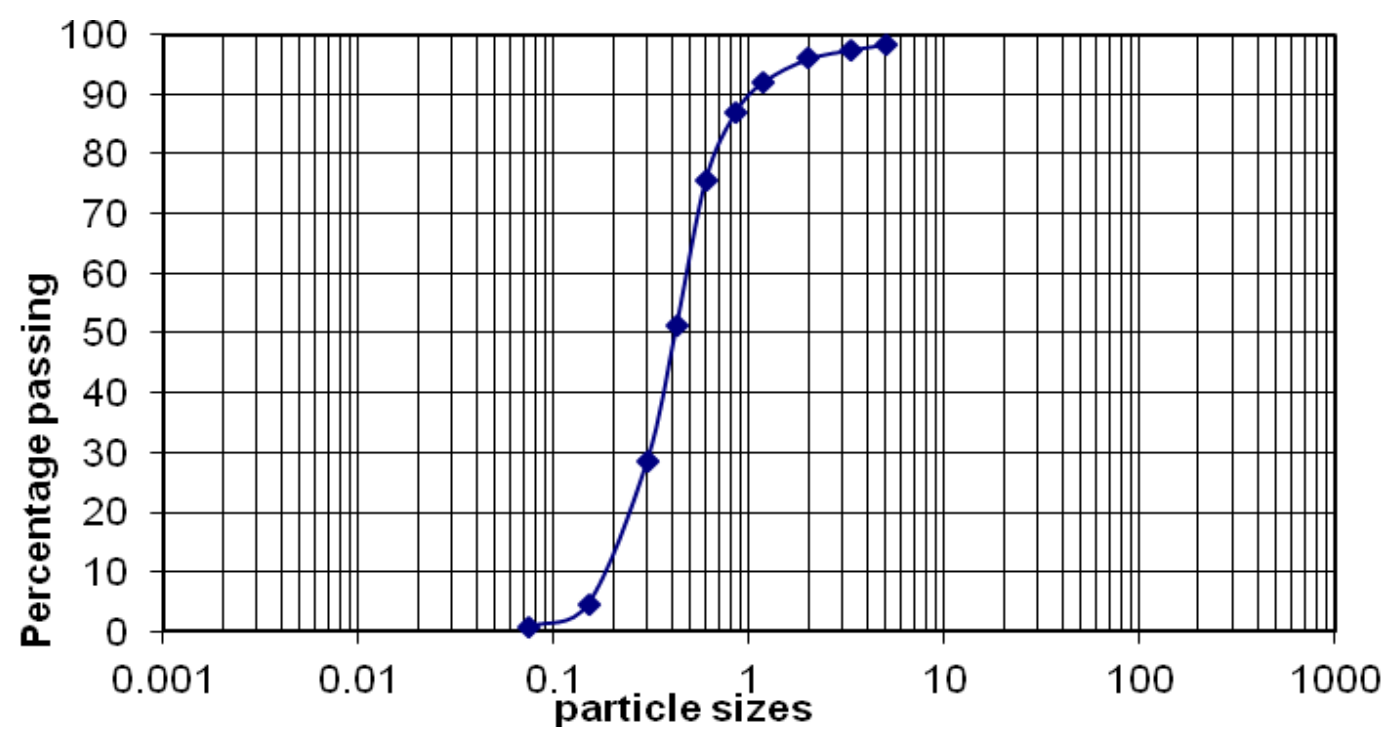

Fig 2: Particle size distribution (SAND) 
As expected, when the percentage of IOT was increased from $0 \%$ to $30 \%$ of sand, and the curing age of SCB increases so does the compressive strength of the SCB. This results agrees with most of the researchers cited that IOT as partial replacement for sand increases the strength of concrete, paving blocks, compressed earth bricks. This may be largely due to the fact that most of the physical properties of IOT being better than that of sand. See figure 3 for variation in the compressive strength with curing age.

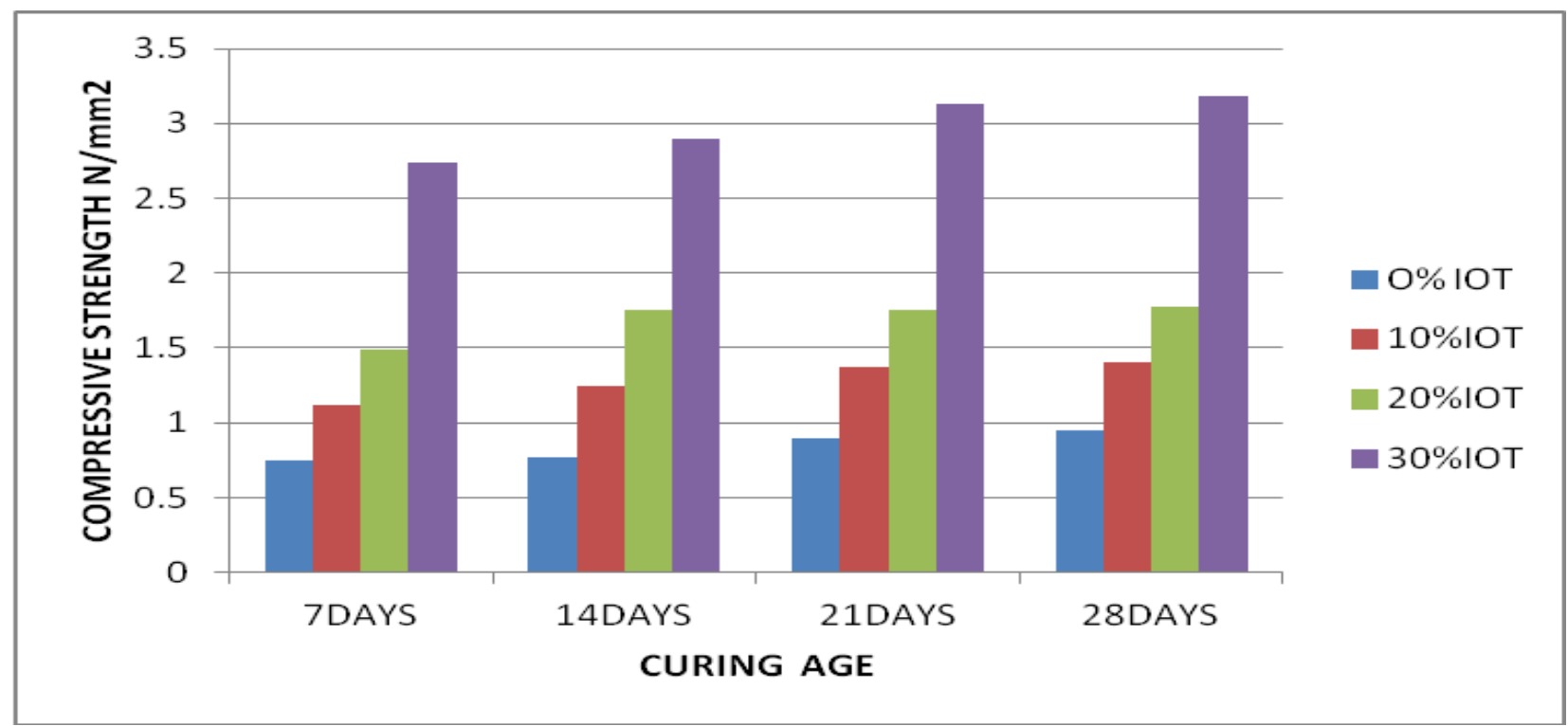

Fig 3: Bar Chart of Compreesive Strength Vs Curing Age

In the figure below, shows the relationship between compressive strength and percentage replacement of sand with IOT at varying curing ages. The trend line for the curves shows an increasing trend from $0 \%$ replacement to $30 \%$ replacement and at varying curing ages. Combining the data together so as to have a general trend see figure 4 . This gives a polynomial of order 3 with a strong regression coefficient $\mathrm{R}^{2}=0.96$. Also table 6 shows the difference between the observed compressive strength and the predicted compressive strength of the IOT SandcreteBlocks. The residual ranges from $0.0705 \mathrm{~N} / \mathrm{mm}^{2}$ to $0.4325 \mathrm{~N} / \mathrm{mm}^{2}$.

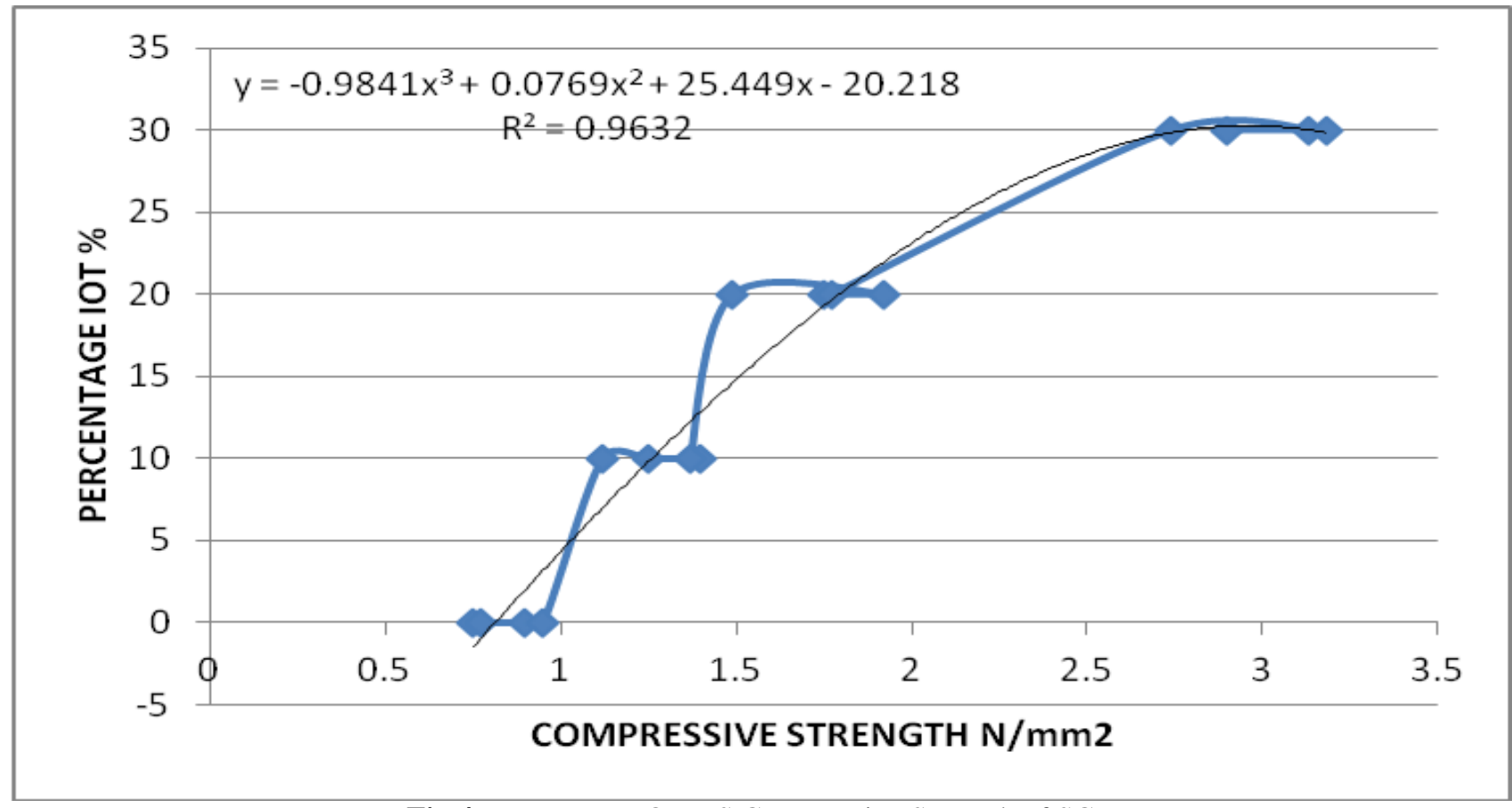

Fig 4; Percentage IOT VS Compressive Strength of SCB 
Table 6: Residuals of the predicted compressive strength in $\mathrm{N} / \mathrm{mm}^{2}$

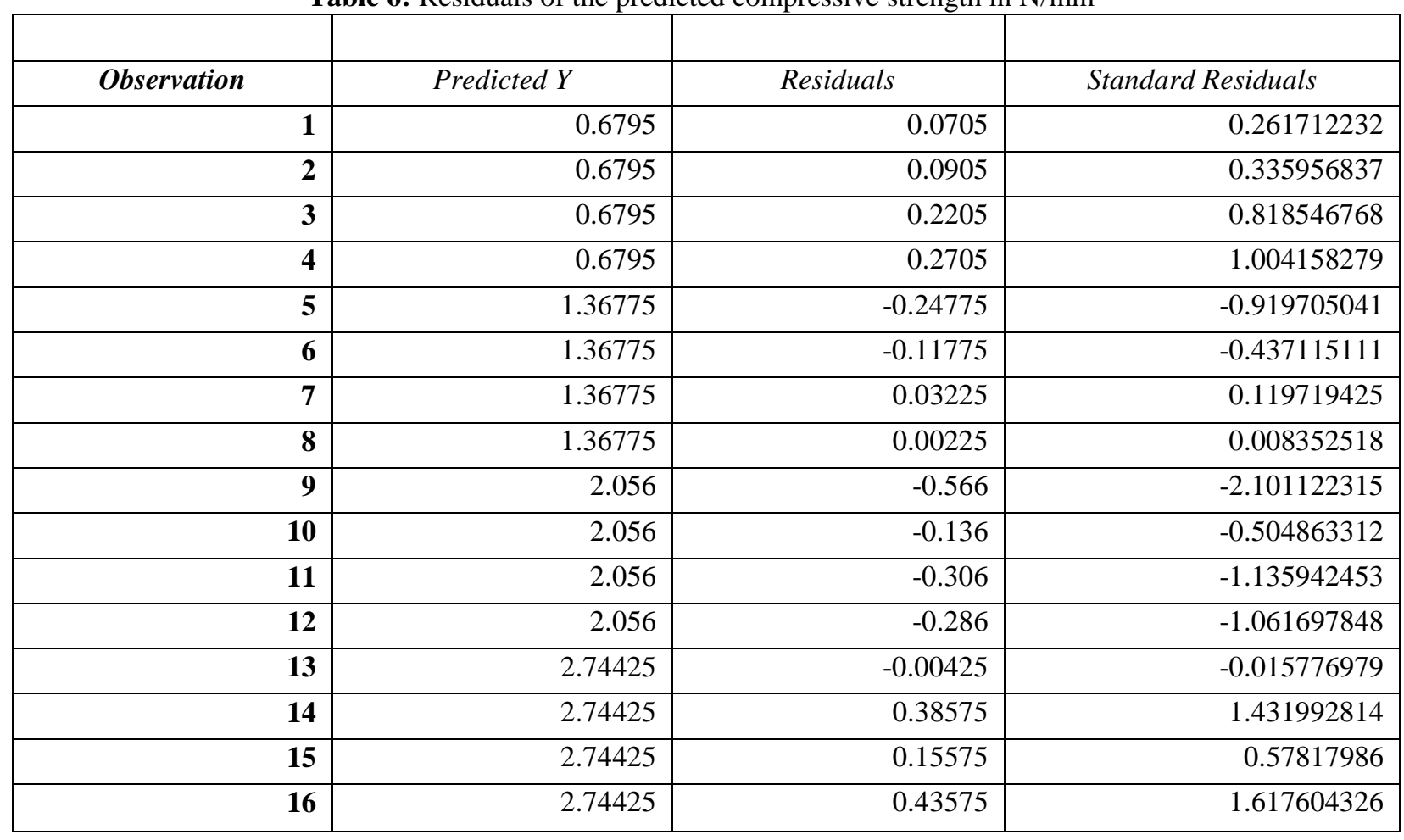

\section{CONCLUSION}

IOT as a material waste can be utilised as a partial replacement for sand in the production of sandcrete block. Its physical properties were better than that of the sand. In sandcrete mix, as the percentage of IOT increases the so does the compressive strength SCB increases. At 28days curing the compressive strength approaches the NIS:2000 recommended strength for 9 inches blocks. The compressive strength of the IOT blocks has the potential to meet up NIS standards: 2000 and could serve as a means to an end that is a way of waste disposal and development of eco friendly sandcrete blocks. See.

\section{RECOMMENDATION}

1. It is recommended that full replacement with sand be investigated since it showed potential of surpassing the standards.

2. It is also recommended that IOT be used in the production of sandcrete blocks especially in areas where tonnes of IOT can be found so as to mitigate its environmental impact.

\section{REFERENCES}

[1] Abdullah, M. (2005). Compressive Strength of SandcreteBlocks in Bosso and Shiroro Areas of Minna, Nigeria,AUJT, 9(2), 126-131.

[2] Akeem A R, Ayodeji K M , Aliu A S (2012). Comparative Analysis of Sandcrete Hollow Blocks and Laterite Interlocking Blocks as Walling Elements International journal of sustainable construction engineering \& technology (issn: 2180-3242 Vol 3, issue 1,2012

[3] Aiyewalehinmi E.O and Tanimola M.O. (2013). Strength Properties of Commercially Produced Sandcreteblock in Akure: Ondo State. International Journal of Engineering Science Invention ISSN (Online): 2319 - 6734, ISSN (Print): $2319-6726$ www.ijesi.org Volume 2 Issue 5 || May. 2013 \| PP.22-33

[4] Ajaka E.O. (2004). "Recovering fine iron minerals from Itakpe iron ore process tailing". ARPN Journal of Engineering and Applied Sciences, 4, (9), 17 - 27.

[5] Baiden, B. K. and Tuuli, M. (2004). Impact of quality control practices in sandcrete blocks production, Journal of Architectural Engineering, 10(2), 55-60.

[6] British Standard Institution, (1992): BSD882. Specification for Aggregate from Natural Source for concrete. British Standard Institution, London, England.

[7] Elinwa A U, Maichibi J E (2014) Evaluation of the iron ore tailings from Itakpe in Nigeria as

[8] concrete material. Advances in Materials 2014; 3(4): 27-32

[9] Mangalpady A,(2012) "Utilization of Iron Ore Tailings in Manufacturing of Paving Blocks for Ecofriendly Mining", IC-GWBT2012, Ahmad Dahlan University, March 23-24.

[10] NIS 87 (2000), "Nigerian Industrial Standard: Standard for Sandcrete Blocks", Lagos, Nigeria, Standards Organization of Nigeria

[11] Sujing Z, Junjiang F and Wei S,(2010) "Utilization of iron ore tailings as fine aggregate in ultra-high 
Performance concrete", Construction and Building Materials, pp. 540-548.

[12] Ullas, S. N., and Venkatarama, B. V.(2010), “ Iron ore tailings as substitute for sand in masonry mortar", Proceedings of the International Seminar on Waste to Wealth, New Delhi, India, pp. 151-155, 2010

[13] Xiaoyan H, Ravi R , Wen N and Victor C. L,(2013) "Development of green engineered Cementitious Composites using Iron Ore Tailings as aggregates", Construction and Building Materials, pp. 757-764. 